\title{
A DIARY OF JAMES MACARTNEY (1770-1843) WITH NOTES ON HIS WRITINGS
}

\author{
by
}

\author{
JOHN L. THORNTON
}

IN his biography of James Macartney, Alexander Macalister (1900) mentions the use of various diaries, letters and notes, most of which cannot be traced, but a chance remark led to the location of a diary in the possession of Professor C. Aylmer Macartney of All Souls College, Oxford (Thornton, 1961). Prof. Macartney kindly made the diary available, giving permission for it to be photocopied and for the material to be published. It has been transcribed, and the copy is housed in the Medical College Library, St. Bartholomew's Hospital, London.

The diary consists of a quarto notebook in which many pages are blank, and in which the pagination is not consecutive. Loosely inserted is a foolscap page describing living conditions of the poor in Ireland. The first four pages of the diary (unnumbered) are headed: 'Facts respecting the Election of a Professor of Anatomy \& Surgery in Trinity College Dublin for the information of the Editor of the Lancet'. This is followed by 'List of my Works', containing thirty-two numbered entries, mainly consisting of titles only, thirteen of these being articles in Rees' Cyclopaedia. Eight pages are then devoted to 'Observations on my own Character', followed by 'Titles and distinctions', and a further eight pages on his family history. The main portion of the diary is in chronological form by years only, and was written many years following the events recorded. A paragraph in the first section mentions that he had reached the age of 70 , which would date the writing at 1840 . The script is difficult to read in sections, for there are many alterations and deletions, and the meaning is not always obvious. After recording an event under a certain year Macartney sometimes corrected it by a later addition, and it is possible that failure of memory resulted in other entries appearing under wrong years. The first entry under 1770 records Macartney's birth, and is followed by 1775 , continuing up to 1814 , after which it jumps to 1835 and then to 1837. A lengthy Appendix headed 'Account of the investigation before the Board of Trinity College on the Charges of Sir Francis Lynch Blosse \& Mr. Sillery in $1825^{\prime}$ completes the diary, and is in the form of a verbatim report of several days' hearings.

Macartney's 'Observations on my own Character' is of great interest as an autoanalytical study, and is followed by a section containing information on his parents and ancestry:

It will appear from the history of my life as recorded and still more from many events only known to myself, that my character has been often misunderstood by even some of my most intimate friends. I have been supposed unrelenting to solicitation-devoid of compassion, more tenuous of my own opinion than desirous to find the truth-penurious \& even miserly, harsh \& tyrannical to those in my power. Now I have known others who did actually possess these qualities gain the reputation of the very contrary, so common is it for people to look no deeper than the mere surface. I have also been considered by some people as unsteady in carrying my 


\section{A Diary of James Macartney}

purposes into effect $\&$ of being indolent $\&$ changeable $\& I$ have been told that I have no predilection for the fair sex, nor love for children by Le Deville the phrenologist. If I was to name any person whom I have ever known as possessing the opposite qualities in the greatest degree that person would be myself. ..

My desire of acquiring excellence in every pursuit I have undertaken has been the chief means of my success in life, which however would have been much greater, with less exertion if I could have descended to the dishonest means so commonly employed for the purpose.

Macartney's diary proceeds to describe his inability to remember his lessons, to retain information derived from books, and to master Euclid and mathematics; yet he acquired a unique knowledge of anatomy and natural history, and was a pioneer in the teaching of comparative anatomy. He built the anatomy and surgical school at Dublin into a centre which attracted hosts of students, and many visiting teachers from abroad. His museum specimens prepared with his own hands augmented his lectures, yet his very success antagonized his colleagues at Dublin, and most of the numerous honours he received were from universities and societies outside Ireland. The following extracts from his diary indicate his own outline of his career, and supplement the information provided by Alexander Macalister and others (see references).

The mother of James Macartney, Mary Maxwell, was the eldest and favourite daughter of a Presbyterian clergyman of Armagh, the friend of John Abernethy (1680-1740), grandfather of John Abernethy (1764-1831) with whom James Macartney was later associated at St. Bartholomew's Hospital. Of his mother Macartney writes in his diary: 'Her tenderness and love for her children was so excessive that they often interfered with her happiness'. His paternal grandfather settled in Armagh about 1727, and was one of the founders of the linen cloth trade there. The elder son succeeded him in the business, but James Macartney's father had received a classical education, and lived at Ballyrea as a gentleman farmer. He joined his brother in town, but continued farming and acquiring land. He had enough money for the period to make it unnecessary for him to educate his sons for a business or a profession, and appears to have been a contrast in character to his wife, being proud, independent, severely honest, and often engaged in disputes with those with whom he conducted business:

\footnotetext{
He acted from principle she from benevolent feeling. She could not continue her resentments, even when they might be justified. He never forgave what he thought unworthy conduct, but it was not the petty vindictiveness for injuries to himself, but a lasting indignation towards a mean or dishonorable action. My father and mother were also differently affected by religion. He seemed to dislike the forms of public worship which he seldom attended. He made Sunday a day of rest in reality, by lying the greatest part of it in bed, where however he was in the habit of praying aloud...

I can have in my own character the qualities that appertained to both that of my father \& mother but as I was more like my mother in person so also do I more resemble her in natural disposition. The tendencies I have received from my father have sometimes antagonized \& at others modified those derived from my mother which accounts for contradictory actions \& feelings that I \& most people from the same reason have exhibited.
}

The first entry of the diary proper is under the date 1770 where James Macartney states that he was born on 8 March in the City of Armagh, and mentions his brothers and sisters. Alexander, Andrew, Matthew, Rosanna (Rose) and Mary grew to maturity, but another brother, John, and twin girls died at an early age. James was the youngest 


\section{John L. Thornton}

of the surviving children, and they were closely attached to each other. Alexander trained to become a surgeon, but died on 25 July 1785 of a diseased liver and dropsy on his return from London during the course; Rose, who assisted James with his reading when he recovered from blindness caused by strumous ophthalmia in 1778, died on 25 May 1781 at the age of twenty-one. Their mother died 'of fever caught by going out at night partially clothed in consequence of a fire in the neighbourhood', and although James records this under $\mathbf{1 7 8 5}$ he later added a note: 'According to an old manuscript she died July 10 1788'. Mary eloped with a Dr. Atkinson against the wishes of her family, and her father never forgave her; he left her only $£ 400$ in his will. The brothers supplemented this from their shares in a manner typical of their attitude towards each other.

James records various events from 1775 onwards, and mentions the treatment he underwent in 1778 for strumous ophthalmia: 'I could not open my eyes for some months from intolerance of the light. I was treated according to the old system of counter irritation. I had blisters behind the ears, a seton in my neck $\&$ an issue in my arm which last was kept in for many years afterwards without any necessity.' Having recovered his sight James Macartney taught himself to read, but in 1779 he caught smallpox and suffered another setback. He became a volunteer in 1780 and gives details of his early military experiences; he was then ten years old. He records boyhood pranks, his youthful attraction to members of the fair sex, and his early education. His father was persuaded to send him to the Endowed Classical School at Armagh where James became well versed in Latin, but he mainly studied at home. He made little progress with mathematics, but was interested in music and in dancing, although his father would not permit him to have lessons in the latter. Under 1786 James records that he read widely, indulged his imagination, and worked in the garden. At the age of eighteen he persuaded his father to permit him to go to Newry to assist his cousins Andrew and Hugh Carlile in their office, and he also superintended the farm at Arhgrove. It was at this time that trouble flared up between the Catholics and Protestants, causing many of the former to move to the west, taking with them the knowledge of linen manufacture.

In the spring of 1790 James Macartney's father 'was seized with an apoplectic fit which ended in palsy. I returned home \& attended him until his death. I had so frequent occasion to rise at night that I did not undress myself for 6 weeks. A second attack of apoplexy terminated his existence in a few days in the latter end of the summer. (September 1.)'

The three brothers were now their own masters, and they moved to Rosebrook in 1791, sharing the properties but executing a deed of partition so that each brother should have command of his own portion. James escorted a Miss Maitland and Anne Carlile to Bristol and he describes travelling conditions at that period, when there were riots in Birmingham:

That town was then in a disturbed state as we found by getting into a mob from which we had a difficult escape. Stage coach travelling was very [different] from what it is now-we spent two days coming from Liverpool to Birmingham. The packets were also abominably lousy. The 3 days I spent on board produced on my head a redundent crop of these vermin. The hairdresser who combed out all the powder \& pomatum and at that time said "he never saw a gentleman so lousy'. 


\section{A Diary of James Macartney}

James Macartney, who lodged in Newry for two years and became an active member of the Society of United Irishmen, formed a similar organization at Armagh. An attempt was made in Dublin to revive the old volunteers under the name of national guards, and James formed a company in Newry, but they were put down by proclamation. He returned to Rosebrook in 1793 and deciding to study surgery, be brushed up his Latin, and in 1794 bound himself apprentice to William Hartigan (1756?-1812), Professor of Anatomy in the College of Surgeons, his indentures being antedated 10 February 1793. During an illness James was confined to the house under the use of mercury, and he took the opportunity to construct a skeleton for the college. Returning home for Christmas, he renewed contact with Miss Ekinhead who had previously rejected his offer of marriage, and James was now accepted. In the summer of 1795 he attended the wedding of his brother and a Miss Donelly, and on 20 August of the same year James himself married. After a fortnight at Bryansford he and his wife visited friends until October, when they returned to Dublin for James to continue his studies. In the summer of $\mathbf{1 7 9 6}$ his brother Matthew joined them on a visit to the hot wells at Bristol, and James records that he had to pay duty on his books by weight, and on the value of some dissections of the nerves and of preparations of the arteries. They visited Wales, staying at Swansea and Tenby, and in the winter moved to London, lodging in Bolton Street. James attended lectures and demonstrations by W. C. Cruickshank (1745-1800), Matthew Baillie (1761-1823) and others. In January 1797 they moved to St. George's Fields for a year to be near Guy's Hospital, where James Macartney became a dresser under William Lucas. During that year he also attended the physiology lectures of Haighton, Henry Cline (1750-1827) and Astley Cooper (1768-1841) lecturing on anatomy and surgery, Smith on botany, and Coleman on veterinary medicine.

In January 1798 the Macartneys moved to Southampton Buildings and then to No. 16 Milman Street. He became demonstrator to John Abernethy (1764-1831) and received $£ 50$ per annum from him. He occupied himself with the improvement of the museum at St. Bartholomew's Hospital, and also instituted the registration of postmortem records, but this was discontinued:

This session I Demonstrated conjointly with Mr. Abernethy. I proposed \& for some time carried into effect registering the dissections made in the dead house $\&$ the corresponding cases. I could not get the medical men \& pupils to continue to furnish me with the latter \& the scheme was given up. What a valuable record this would have become in some years if it had been properly followed up! Abernethy paid $1 \frac{1}{2}$ guinea for the book to his credit be it said!

James Macartney dissected so constantly during the summer of 1799 that his health became impaired, and he could not walk without a stick. He went on a walking tour through unfrequented parts of Wales for three weeks, and was so re-invigorated that he 'undertook all the demonstrations that season.' That winter Sir Everard Home had promised Macartney his support in securing the lectureship in comparative anatomy at the College of Surgeons, to which Sir Everard was himself elected, but Macartney qualified himself for the appointment by taking the membership examination at a day's notice, and was successful.

Early in 1800 John Ekinhead, James' brother-in-law, became financially embarrassed owing to trouble over a ship, and was arrested. James stood bail for him but later 


\section{John L. Thornton}

Ekinhead was committed to the King's Bench. A Scottish merchant undertook to manage the ship, Macartney agreeing to reimburse him for any loss. The ship was later sold, and Macartney was asked for several hundred pounds to compensate the merchant. He had to sell some of his property in Ireland to meet this demand, although he believed there was no legal obligation upon him to pay the money. John Ekinhead died of fever in Africa in 1802.

The summer of 1800 was spent at Niton in the Isle of Wight dissecting animals and making preparations for a course of lectures on comparative anatomy and physiology which he had obtained permission to give at St. Bartholomew's Hospital. He was still demonstrating in anatomy, and also involved in the affairs of his brotherin-law:

In order to compass so much labour I was in the habit of sitting up the whole of every second night \& often more frequently \& as making preparations was a part of my work I usually sat up in the kitchen-I had the opportunity on one occasion of seeing an extraordinary invasion of Rats that had multiplied to an immense number in the next house to mine then waste. They came in such numbers that the floor where I sat was a rat colour and after running about \& searching for food for some [time] they quietly returned, convincing me of the stories told of rats in great numbers attacking people were false.

Macartney's first course of lectures on comparative anatomy and physiology was delivered in the spring of 1801 , and not thinking much of his future prospects in London, he took a cottage at Shanklin, which he decorated with his own hands. He occupied himself in supervising William Ross's translation of two volumes of Cuvier's Lectures on Comparative Anatomy, published in 1802, and professionally in treating the wounds caused by an engagement between smugglers and cutter's men.

Each spring James Macartney went up to London and delivered his lectures on comparative anatomy at St. Bartholomew's Hospital. He had resigned his demonstrations to William Lawrence in 1802, and in the following year complained that 'The class gave no promise of increase: probably Lawrence did not recommend the course altho he continued to attend himself.' It is of interest to note that James Parkinson (1755-1824), after whom Parkinson's disease is named, author of Organic Remains of a Former World, three volumes, 1804-1811, and (Sir) William Lawrence (1783-1867) author of the controversial Lectures on Physiology, Zoology, and the Natural History of Man, 1819, both attended Macartney's lectures and were probably stimulated by them.

In 1803 Macartney was offered the Surgeoncy of the Royal Militia, which he accepted, and after disposing of his cottage at Shanklin, he and his wife travelled around with the regiment, which was stationed for various periods at Canterbury, Margate, Hythe, Deal, Sheerness, Bristol, Milford, Bexhill, and Dungeness Forts. He was writing articles for Rees' Cyclopaedia and states that he 'was now engaged as a regular contributor at a higher rate than any other, because at that time no other person understood the subject.'

At Herne Bay he conducted experiments on the effects of injury to fish, leading to his discovery of the non-inflammatory nature of the process of reparation. In 1806 he gave two courses of lectures, one 'at the request of Brodie \& a dozen Scotchmen. Charles Bell promised to attend but did not ... This course was given at Mr. Lambert's drawing room before breakfast.' 


\section{A Diary of James Macartney}

During this year his brother Matthew died intestate, and although his property should have gone to their brother Andrew, the latter gave James the Townland of Tullylegg. When bringing the deeds over to James, Andrew was attacked by robbers and severely wounded. In 1808 Macartney was kept busy treating troops that had been in Sir John Moore's retreat, and the regiment volunteered for service overseas: 'The regt. both Officers \& men this year offered to serve in Spain, Portugal or any part of Europe. We were thanked which was all we got for being such fools.'

The following year he spent some time writing a work on surgical anatomy which he never completed, and on the anatomy of fishes, but he also engaged in social life and lodged at first in Romney and then at Lydd. In the year 1810 Macartney 'caught the Marsh Remittent Fever which ended in ague', and after recuperating at Tunbridge Wells 'we went to London \& there gave my 10 th and last course of Lectures to only 3 pupils so much had the course at that time gone out of fashion in a great degree from my absence from town. Lecturers should be on the spot. I attended Les Jas. Smith's Lectures on Botany with only three other pupils altho' he came from Norwich for the purpose of giving the course.'

Early in 1811 the regiment to which Macartney was attached volunteered for service in Ireland, but before they left Hythe a large grampus ran ashore at Hythe, and Macartney decided to dissect it and preserve the skeleton. He put the uncleaned skeleton in the river at Lydd to macerate and then persuaded some of the soldiers to boil the bones in a spare barrack cauldron: 'The bones were then packed in an oil barrel and while so enclosed a multitude of insects, I suppose minute mites, passed into the bones \& passed through their cellular structure completely cleaning it out of all oily matter. The route came for Bristol in June. I left the regt. at Guilford to take the grampus by the waggon to London \& joined it at Brentford. The insects were so numerous in the barrel that they were skipping in \& out in hundreds.'

He occupied most of his spare time in 1811 and early 1812 writing the 'Anatomy of mammalia' for the Cyclopaedia. It was at this time that his brother Andrew showed signs of mental derangement, and despite looking after him for a while, James Macartney was forced to place his brother in Dr. Jackson's Asylum, where he died of an apoplectic fit: 'This was the most trying event of my life to part thus with my dearest brother \& my most disinterested friend gave me a feeling of desolation beyond what I ever felt before or since.'

Fortunately Macartney found plenty to occupy his mind, as on 21 June he was elected Professor of Anatomy and Surgery at Trinity College, Dublin, 'for which I had proposed myself in the spring with little hope of success'. This was not without opposition from certain quarters, which was continued during Macartney's tenure of the office. He returned to London to remove his specimens, and while there engaged Mr. Cross as a demonstrator. Back in Dublin his first public course of lectures was crowded out, and he immediately set about establishing a pathological museum: 'Cross \& I were obliged to undertake the resurrection of bodies with very little assistance. On one occasion I was taken prisoner \& not liberated before morning \& treated with the greatest indignity by the Cheshire Militia.'

Early in 1814 Macartney proposed the establishment of an Eye Infirmary, with Cross as surgeon and himself as physician, but it was insisted that Cross should 


\section{John L. Thornton}

become an Irish Licentiate. Against Macartney's advice Cross failed to prepare himself for the formality he expected, and was rejected. Cross resigned in the autumn but left 'some exquisite preparations of the eye \& ear'. Macartney gave a gratuitous course of lectures on comparative anatomy in this year, but it was poorly attended. In November of that year he founded the Medical Society of Trinity College.

Macartney's diary then jumps to the year 1835, and under this date he records:

'In the beginning of the winter I had the dispute with the Board concerning the hour for giving the Surgical Lectures of which a full account is preserved in my papers.'

The final entry in the diary proper is under 1837 and reads: 'In consequence of repeated annoyances in the past of the Board or rather the present $\&$ having sold my collection I resigned my professorship on the 11 of July 1837 . The following October Mr. Harrison was appointed my successor which had been determined for some time by the provost $\&$ all the Board acquiessed except Dr. Wall who voted for Jacob. Dr. Carlile had not a single vote altho' his qualifications were superior to those of both the others.'

The Appendix is devoted to an 'Account of the investigation before the Board of Trinity College on the Charges of Sir Francis Lynch Blosse \& Mr. Sillery in 1825', and is apparently a verbatim report of the proceedings with copies of letters, despite the fact that Macartney states that he was refused permission to have a shorthand writer present. Macartney was accused of being irreligious and immoral in his lectures. Sir Francis Lynch Blosse attended part of a course and decided that they were disgusting and obscene'. He mentioned that the religious opinions of certain students had been adversely affected by Macartney's lectures, and by Lawrence's book which Macartney made available in the library for students. The Rev. Anthony Sillery also criticized the detailed lectures on the genital organs, and stated that Macartney had condemned the attitude of the Bishop of Chester in preventing the admission to hospital of females suffering from venereal disease. Sillery said that the class had been shown a female subject with a stick thrust into the private parts, but crossexamination revealed that the lecturer was explaining the introduction of a silver female catheter. It was also revealed that Macartney had refused to apply to the Board for Sillery's brother to be examined for a degree without the proper number of certificates. Several witnesses who had attended his lectures testified for Macartney, and he was requested to submit a copy of his introductory lecture to the Provost. This he sent together with a register of every lecture delivered during the course, and on 13 December 1825 he sent a lengthy letter to the Board. This mentioned that he had 135 witnesses ready to give evidence in his favour, but they were not required, and the decision of the Board, officially communicated to Macartney on 15 December stated in words by the Provost: ' . . . that the Board having met \& compared their different notes taken of the evidence, had requested him to communicate to me their unanimous decision, that the charges of irreligion immorality \& indecency against me, were without foundation, \& that there existed no doubt in any one of their minds, with respect to the purity of my intentions.'

Macartney's reappointment as Professor of Anatomy and Surgery was confirmed at intervals of seven years, but as the result of numerous quarrels with the authorities 

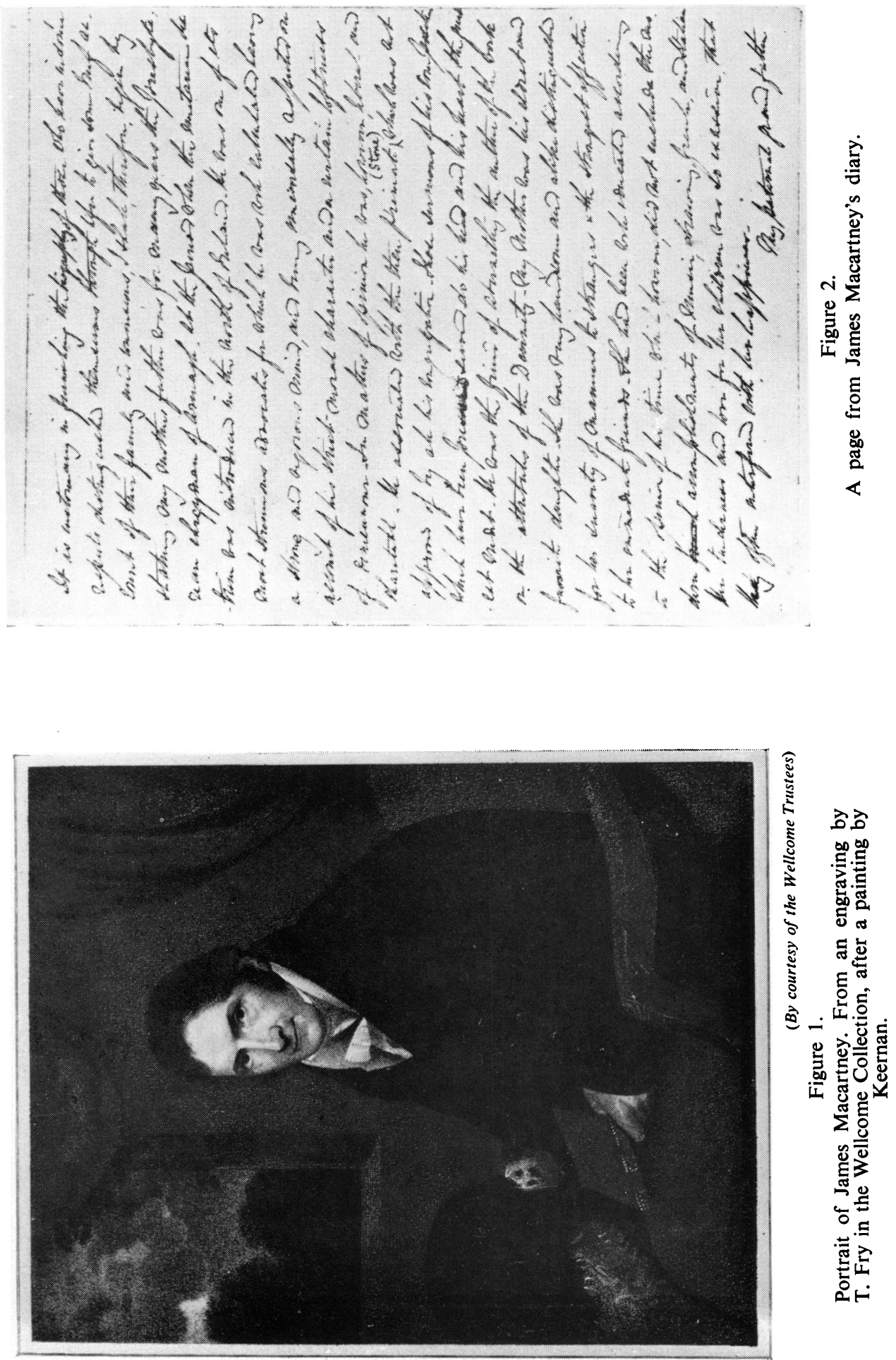


\section{A Diary of James Macartney}

he resigned on 11 July 1837. He died on 9 March 1843, and thus terminated an eventful career, the latter part of which was occupied with quarrels with the authorities in Dublin. These events have tended to obscure Macartney's contributions to comparative anatomy, pathology, and to anatomy in general. An evaluation of his writings and their influence on later literature is overdue, and a brief survey of their extent suggests that they are worthy of closer investigation by a competent authority.

His supervision of William Ross's translation of the first two volumes of Cuvier's Lectures on Comparative Anatomy, 1802, has already been mentioned, and Macartney performed a similar function for the translation from the Latin of $A$ Description of the Arteries of the Human Body Reduced to Tables, by Adolphus Murray, London, 1801. In his Advertisement to the book Macartney states: 'Whilst this translation was in the press, information was received that another of the same Work had appeared in Edinburgh. Upon perusing that publication, however, there seemed no reason for abandoning the present undertaking.'

Macartney's Observations on Curvatures of the Spine, Dublin, 1817, was also published in a periodical (Trans. Roy. Irish Acad., 1818, 13, 13-24), and in a French translation, Paris, 1826. His Lecture on the Uses of Anatomy and Physiology in Various Branches of Knowledge, Dublin, 1826, was followed by another book after his retirement, bearing the title $A$ Treatise on Inflammation, London, 1838 and Philadelphia, 1840. Macartney's Advertisement to this states: 'The present Treatise contains the theory and practice, respecting the subject of inflammation, which I have taught during many years in my lectures on surgery. Its publication did not become necessary until I had resigned my professorship in the University of Dublin, as I had annually the best means, perhaps, of promulgating and explaining my views in the form of lectures.'

This book was very enthusiastically received by reviewers in the medical press, the Lancet calling it 'this important and highly original work', and proceeding: 'In conclusion, we do not hesitate to pronounce the "Treatise" of Dr. Macartney to be the most original medical work which has appeared since the days of John Hunter.' (Lancet, 1838-9, i, 238-41, 268-71).

In his diary Macartney several times mentions that he was writing for Rees' Cyclopaedia, and it is probable that his articles in this contain the results of much original research. In his Preface the editor, Abraham Rees, states that it was the 'production of incessant labour of almost twenty years', and it was published in parts. The Cyclopaedia: or Universal Dictionary of Arts, Sciences, and Literature, appeared in thirty-nine volumes with six volumes of plates, dated 1819 to 1820 . Macartney's contributions range from sections of columns to eighty-seven pages in double columns, and are: Anatomy, comparative, and Anatomy, vegetable (Vol. 1.); Bezoar, and Beast (Vol. 2); Birds, anatomy, fifty-three pages (Vol. 4); Branch, Bud, and Bulb, all in vegetable anatomy (Vol. 5); Classification of animals for comparative anatomy, twenty-six pages (Vol. 8); Egg, in comparative anatomy (Vol. 12); Fish, or Fishes, anatomy of (Vol. 14); Incubation, in comparative anatomy, twenty pages (Vol. 19); and Mammalia, anatomy of, eighty-seven pages (Vol. 22). William Lawrence wrote the articles on Insects, Reptiles and Vermes because, as he explained, Macartney was prevented from writing them by other occupations. 


\section{John L. Thornton}

Macartney contributed two papers to the Philosophical Transactions of the Royal Society, the first, 'Observations upon luminous animals', Phil. Trans., 1810, 258-93; Abstracts of Papers printed in Phil. Trans., 1800-1814, 1, 379-83; also printed in J. Nat. Philos., Chem., Arts, (Nicholson), 1811, 28, 41-55, and elsewhere), contains the results of his research on the sea-shores of the various places where he was stationed. This was followed by 'An account of an appendix to the small intestines in birds' (Phil. Trans., 1811, 257-60; Abstracts of Papers printed in Phil. Trans., 1800 $1814,1,404)$. He also read papers at several annual meetings of the British Association for the Advancement of Science, and reports of these were printed in the Notices and Abstracts of Communications section of the Report of the . . British Association for the Advancement of Science, as follows: 'On some parts of the natural history of the common toad', 1833, pp. 441-44; 'Abstract of observations on the structure and functions of the nervous system', 1833, pp. 449-54; 'An account of the organ of voice in the New Holland ostrich', 1836, p. 97; 'On means of preserving animal and vegetable substances', 1836, pp. 99-101; 'On the structure of the teeth, with an account of the process of their decay', 1836, pp. 115-17; 'On the means employed to suppress haemorrhage from arteries', 1839, pp. 97-99; 'On the rules for finding with exactness the position of the principal arteries and nerves from their relation to the external form of the body', 1839, pp. $102-4$.

Several papers by Macartney were published in the Provincial Medical and Surgical Journal: 'On the ligament of the cauda equina', 1840-41, 1, 7-8; 'On medical reform and the remodelling of the profession', 1840-41, 1, 282-85; 'The medical conference' (Corres.), 1840-41, 1, 399; 'Cambridge Anatomical Museum' (Corres.), 1841, 2, 443; 'Account of an apparatus for applying water in the manner of irrigation', 1841, 2, 342-43; 'Evolution of light from living animals', 1842, 2, 218-19; and 'On the minute structure of the brain in the chimpanzee and human idiot, compared with that of the perfect brain of man; with some reflections on the cerebral functions', 1842-3, 5, 166-68. This latter had previously appeared in Transactions of the Royal Irish Academy, 1843, 19, 322-28. Other publications include 'Sur la structure des bronchies dans les foetus de squales', Journal de Physique de Chimie et d'Histoire Naturelle, 1818, 86, 157-58; and 'Cases of extra-uterine foetation', Dublin Journal of Medical and Chemical Science, 1835, 7, 412-14.

The Royal College of Surgeons of England Library houses a manuscript by William Clift with the title "Copy of Abstract of the Catalogue of Preparations in Dr. James Macartney's Collection; from Dr. Macartney's M.S. June 20, 1835. Extracts from Dr. Macartney's Catalogue. June 24th, 1835'. This consists of a booklet of about forty quarto pages, with a separate single folio sheet, and the references are to the page numbers of the original, which extend to page number 361. Macartney's museum went to Cambridge because Dublin did not appear interested in its acquisition.

\section{ACKNOWLEDGEMENTS}

I must express sincere thanks to Prof. C. Aylmer Macartney for permission to publish these extracts from the diary, and to Mrs. Sally Burgess for transcribing most of it. Also to Prof. J. D. Boyd, Dr. John Fleetwood and Dr. J. D. H. Widdess for correspondence while attempting to trace Macartney material. Finally, to Mr. W. R. LeFanu, Librarian of the Royal College of Surgeons of England, for assistance provided personally, and in his Library. 


\section{A Diary of James Macartney}

\section{REFERENCES}

ERINENSIS, 'Sketches of the surgical profession in Ireland. No. VII. Mr. Macartney', Lancet, 1825, 7, 85-89. 248-52. Page 308 carries a letter from Macartney replying to this, correcting certain points, denying that he was 'stricken with years', and stating 'that I every year refuse more money than he thinks I receive'.

FleEtwOOD, JoHN F., History of Medicine in Ireland, Dublin, Browne \& Nolan, 1951, 53-54. Idem., 'The Irish resurrectionists', Irish J. med. Sci., 1959, July, 309-21.

MACAlister, AleXANDer, James Macartney . . . a Memoir, London, Hodder \& Stoughton, 1900.

POWER, SIR D'ARCY, in Dictionary of National Biography, Supplement 3, London, Smith, Elder, 1901, 116-17.

ThORNTON, J. L., 'James Macartney (1770-1843)', St Bart's Hosp. J., 1961, 65, 121-23.

WidDEss, J. D. H., The Royal College of Surgeons in Ireland and its Medical School, 2nd ed., Edinburgh and London, E. \& S. Livingstone, 1967, 23-25, 27. 